\title{
Teaching English Literature in Costa Rican Experimental Bilingual High Schools: EfL Teachers' Academic Training
}

\section{Enseñanza de la Literatura Inglesa en liceos experimentales bilingües costarricenses: la formación docente}

Karla Araya Araya (1) arayaka@gmail.com

Priscila Campos Rosales (2) priscilla1081@hotmail.com

Erika González Mora (3) ericka08gm@hotmail.com

Gerardina Marín Madrigal (4) gerarmarin@yahoo.com

Kattia Rojas Suárez (2) kattiarojas33@yahoo.com

Catalina Sánchez Alvarado (5) catalina sanchez@costarricense.cr

(1) Universidad de Costa Rica

(2) Colegio Técnico Profesional Carrizal

(3) Costa Rican Experimental Bilingual High School of Naranjo

(4) Colegio Nocturno Palmares and Colegio Moreno Cañas

(5) Experimental Bilingual High School of Grecia

(Received: August 21, 2014; accepted for publishing: February 2, 2016)

How to cite: Araya, K., Campos, P, González, E., Marín, G., Rojas, K. \& Sánchez, C. (2017). Teaching english literature in costa rican experimental bilingual high schools: EFL teachers' academic training. Revista Electrónica de Investigación Educativa, 19(3), $126-142$. Retrieved from https://doi.org/10.24320/redie.2017.19.3.863

\begin{abstract}
This article presents the most relevant results found in the "Licenciatura" graduation research project for the BA in Teaching English offered by the University of Costa Rica, Campus Occidente. The work, entitled "Strengths and Weaknesses in Teaching English Literature in Experimental Bilingual High Schools of the Western Educational Region of Costa Rica: A Study from the Teachers' Perspectives", was conducted in 2012 and 2013. $36 \mathrm{EFL}$ teachers participated. This paper presents results on the strengths and weaknesses of teachers' academic and professional training in light of the implementation of the English literature syllabus of the Costa Rican Ministry of Public Education (known by the acronym MEP in Spanish). Qualitative and quantitative methodologies were used. Interviews were conducted with participants and English advisors and an online survey was also used. Results show that most EFL teachers do not feel trained to deal with the English literature syllabus because teaching literature is not their major, but the MEP has assumed that mastering the language is sufficient for an English teacher to teach literature. Most teachers reject this presupposition as they think that the MEP'S English literature syllabus focuses on literary content rather than using literature to teach and learn English. Teachers assert that there is a discrepancy between their academic training and what the MEP expects them to do.
\end{abstract}




\section{Resumen}

Este artículo presenta los resultados más importantes derivados del Trabajo Final de Graduación de licenciatura en la enseñanza del inglés de la Universidad de Costa Rica, sede de Occidente, realizado en el período 2012-2013, titulado "Fortalezas y debilidades de la enseñanza de la literatura inglesa en los Liceos Experimentales Bilingües (LEB) de la región educativa del Occidente de Costa Rica: un estudio desde la Perspectiva Docente", que aborda las fortalezas y debilidades encontradas en el área de la formación docente del profesorado. La metodología utilizada fue mixta; se aplicaron entrevistas y un cuestionario en línea a 36 docentes de inglés y una supervisora educativa. Los resultados demuestran que la mayoría del profesorado no se siente capacitado para enseñar literatura inglesa porque no es esa su disciplina. En este sentido, la principal falacia creada por las autoridades gubernamentales es que el buen dominio del inglés presupone la capacidad y el conocimiento para enseñar literatura inglesa; algo que el profesorado desmiente, afirmando que la propuesta no se enfoca en la enseñanza-aprendizaje del inglés, sino en la enseñanza de la literatura. En consecuencia, el grupo docente considera que hay un vacío importante entre la formación profesional recibida y lo que el MEP espera que ellos hagan.

Palabras clave: Literatura inglesa, secundaria, educación bilingüe, formación del profesorado, profesores de inglés.

\section{Introduction}

In 1995, the Costa Rican government began to developa more intensive educational-political agenda in the field of English language teaching and learning. One of the most important results of such policies was the foundation of the first Experimental Bilingual High Schools (EBHS). In the Western Educational Region of the country (which includes the communities of Palmares, Naranjo, San Ramón, and Sarchí), the Ministry of Public Education (known by the acronym MEP in Spanish) transformed the Academic High School of Palmares into an Experimental Bilingual High School. In the last ten years, three more Experimental Bilingual High Schools have been opened in the region. In these schools, the MEP initially proposed more English teaching hours with the main goal of strengthening and improving students' communicative speaking, listening, and writing skills, but by 2010, the MEP launched the implementation of an English literature curriculum to improve students' English proficiency and develop their aesthetic literary appreciation.

However, despite the fact that the time allotted to teach and learn English in the EBHS was increased, the communicative language competence of the student and teacher population has not met all the MEP's academic expectations. This became evident with the results obtained in the first and second national studies on teachers' command of English carried out by Costa Rica Multilingüe. ${ }^{1}$ This first diagnosis was made in 2007. The Costa Rica Multilingüe National Plan report (2008) included a small sample of 705 alumni from public schools (including EBHS) and private institutions. Most students scored below the desired intermediate and advanced proficiency level that the Common European Framework (CEF) establishes for speakers of a foreign language.

The CEF divides English language proficiency into six levels of communicative competence ranging from the lowest to the highest level as follows: A1, A2, B1, B2, C1, and C2. In this taxonomy, A1 and A2 refer to the basic mastery of a second language (L2). B1 and B2 represent intermediate mastery while C1 and C2 reflect an advanced knowledge of L2.

The results of the First Report of Costa Rica Multilingüe (2008) concerned the Costa Rican governmental authorities; the data revealed that $65 \%$ of the student population had an A1 proficiency level in English, $24 \%$ of them were classified as A2, $6 \%$ of them were at the B1 level, $3 \%$ earned a B2 grade, and only $2 \%$ of students were considered advanced speakers of English (C1). In other words, the majority of

\footnotetext{
${ }^{1}$ This is a governmental institution that aims to improve primary and secondary Costa Rican education through courses and training programs offered to students and teachers of foreign languages such as English. It was created and declared of national interest on March 11th, 2008 during the administration of President Arias Sánchez.
} 
participants (a total of $89 \%$ ) demonstrated only a basic command of English. In contrast, $9 \%$ of them showed an intermediate knowledge of English and only $2 \%$ demonstrated an advanced proficiency level. Evidently, these poor results indicated that the MEP's goals were not being accomplished.

The report also revealed that teachers' English language proficiency was another issue. $91 \%$ of English teachers working for the MEP participated in this diagnosis. From that sample, $7 \%$ of the participants were in the $\mathrm{A} 1$ band, $32 \%$ in the $\mathrm{A} 2$ band, $28 \%$ in the $\mathrm{B} 1$ band, $20 \%$ in the B2 band, and only $13 \%$ scored high enough to be included in the $\mathrm{C} 1$ band (the advanced level required for English teachers). In other words, $39 \%$ of the English teachers working for the MEP had basic linguistic and communicative skills while $48 \%$ of the sample demonstrated intermediate-level mastery of English.

To improve English language education in the country, MEP decided to address the language proficiency problems (of both teachers and students) from two main perspectives. On the one hand, the mep started to implement a training plan for English teachers. Through Costa Rica Multilingüe, in 2009 the government began to offer a series of instructional courses to improve teachers' English language competence, paying particular attention to those who scored in the $A 1, A 2, B 1$, and $B 2$ bands. The plan also included training on teaching methodologies and evaluation strategies for teachers identified in the $\mathrm{B} 2$ and $\mathrm{C} 1$ bands.

A second policy dealt with the implementation of some academic and administrative decisions related to both the English language programs and hiring regulations. The MEP has updated and proposed different syllabi to teach English according to the educational emphasis of high schools. One of those differentiated curricula is the English literature syllabus, which is designed to be implemented in EBHS. These high schools have also been provided with language laboratories and many other printed and technological didactic materials. Moreover, the number of teaching hours has been increased. In regard to hiring policies, teachers who score in the intermediate (B1 and B2) and advanced (C1) levels are given preference in the EBHS. They are also the first candidates to take tenured positions in the national recruiting process.

But the repercussions and effects of these decisions and actions have not been fully studied. In the academic field, there is little information about the impact that the new English literature syllabus for EBHS has had on the students' command of English. It seems that governmental authorities have just assumed that having the best academic teachers will guarantee students' high mastery of the language. The fact that the English literature syllabus started out as a pilot plan and the MEP assumes that any EFL teacher can teach English literature, have also limited research proposals in this field.

Consequently, a Licenciatura graduation research project was conducted in 2012 and 2013 at the University of Costa Rica, Campus Occidente. The study, entitled "Strengths and Weaknesses of Teaching English Literature in the Experimental Bilingual High Schools of the Western Educational Region of Costa Rica: A Study from the Teachers' Perspectives" intended to analyze the state of the art of teaching English literature in EBHS in the western educational region of Costa Rica. Three specific objectives were proposed: 1) to identify the positive aspects and gaps in the professional training EFL teachers have in regard to the demands and expectations of the current English literature syllabus for Experimental Bilingual High Schools; 2) to determine the strengths and weaknesses in the methodological, didactic and evaluative fields that, from the EFL teachers' perspective, are influencing the process of teaching English literature in Experimental Bilingual High Schools; and 3) to point out the positive and negative aspects of the MEP's proposal to teach English literature and language by analyzing its theoretical and pragmatic coherence. $36 \mathrm{EFL}$ teachers participated in mixed research that interviewed participants and English advisors, in addition to offering an online survey to gather data.

For reasons of length, this paper presents the results relating to the first specific objective of the aforementioned study, which is to identify the positive aspects of, and gaps in, the professional EFL training that teachers have in regard to the demands and expectations of the current English literature syllabus for Experimental Bilingual High Schools of the western educational region of Costa Rica. In this article, the researchers intend to open up the discussion on the academic and socio-educational impact of the current implementation of the cited syllabus. 


\section{Methodological Considerations}

This study used mixed methods research (qualitative and quantitative methods), but favored quantitative techniques. Creswell (2003) proposes that:

[i]n a qualitative project, the author will describe a research problem that can be understood by exploring a concept or phenomenon. I have suggested that qualitative research is exploratory and the researchers use it to explore a topic when the variables and theory base are unknown. (p. 9)

In regard to the present research study, the state of the art of teaching English literature in Costa Rican EBHS is uncertain because there have been no previous studies. Consequently, an exploratory phase was needed to establish the variables proposed here. According to Creswell (2003):

Characteristics of a qualitative research problem are: (a) the concept is "immature" due to a conspicuous lack of theory and previous research; (b) a notion that the available theory may be inaccurate, inappropriate, incorrect, or biased; (c) a need exists to explore and describe the phenomena and to develop theory; or (d) the nature of the phenomenon may not be suited to quantitative measures. (p. 120)

Here, the "immaturity" of the concept is not found in the epistemological terminology associated with literature and language teaching, but in the premature implementation of the English literature syllabus for EBHS. No information about this process is available because no studies were found in this area and educational context.

The fact is that EFL teachers, and not English literature teachers, are implementing the MEP's literature syllabus. This situation fuels a debate on the notion and theoretical basis that the MEP has used to justify the implementation of the aforementioned syllabus in EBHS.

On the other hand, this study obtains data through surveys and interviews. Buendía (1998) defines the term survey as "a research method, capable of responding to problems either in descriptive terms or by establishing relationships between variables, following the systematic collection of information, according to a previously established design to ensure the accuracy of the information obtained" ( $p$. 120). In this respect, survey research allowed the researchers to obtain information in order to a) describe the existing conditions of nature [in this case the state of teaching English literature in Experimental Bilingual High Schools in the Western Region], b) identify norms or standards to compare these conditions [among teachers of English literature in EBHS], c) determine the relationship between specific events (strengths and weaknesses in the areas described, in relation to the successful development of English literature teaching).

Two types of instruments were designed for this research: Interviews and a survey. Interviews were the first data collection instrument designed. Structured and semi-structured interviews were used. Initially, structured interviews were conducted to identify participants' socio-demographic information, teaching experience, and general perceptions about the implementation of the MEP's English literature syllabus. These kinds of interviews reduced biased information because they provided a corpus database to be validated and expanded with semi-structured interviews and the survey. Afterwards, semi-structured interviews were applied randomly to 10 participants in order to obtain clarifications and further explanations, and validate questions for the online survey.

Finally, a personal numbered survey or poll was also very important for this research. The platform Lime Survey was used to apply an online questionnaire. This free-source application enables users to develop and publish online surveys and collect responses with no programming required.

The trial questionnaire used contained five sections. The first two sections dealt with the personal information, teaching experience, and background education of the sample population. The other three 
sections focused on methodology; namely, the syllabus and evaluation that teachers used in their English literature classes in EBHS.

The survey included a total of 69 questions, 65 closed-ended questions and 4 open-ended questions. The first section, related to personal information and teaching experience, contained 10 closed-ended questions. The second section, about teachers' background education, had 12 closed-ended questions and 1 open-ended question. In the third section, there were 8 closed-ended questions about methodology. The fourth section had 16 closed-ended questions regarding evaluation. Finally, the fifth section included 16 questions (13 closed-ended questions and 3 open-ended questions) about the MEP's English literature syllabus. Teachers were also asked to provide any additional information they may consider valuable to expand the aspects under analysis.

All instruments focused on four main categories of analysis: the MEP's English literature syllabus, teachers' academic training, teaching methodology and evaluation strategies used by teachers. But, as previously explained, this article will only discuss the results on teachers' academic training.

The population selected for this research study includes 36 EFL teachers (25 women and 11 men) who worked as literature teachers in the EBHS of the Western Educational Region of Costa Rica (which are Palmares, San Ramón, Naranjo and Sarchí). It was a full sample, as all teachers responsible for English literature classes during the year 2012 participated as subjects of the research.

The group was very diverse in terms of gender, age, education and teaching experience. But in general terms, ages ranged from 20 to 50 years old; $22 \%$ of them had less than 5 years' working experience, $47 \%$ had worked for more than 6 years, and $31 \%$ had more than 10 years of teaching experience. But experience in teaching literature is minimal because their professional expertise has been as teachers of English to speakers of other languages (TESOL).

\section{Theoretical Reference}

The connection between literature and foreign language teaching and learning is not new. Experts in language teaching have rejected or promoted its use in language classrooms depending on the aims of different teaching approaches. One of the first language teaching and learning methods developed to deal with literature in the language classroom was the formalist approach, which views language/literature under the grammar translation perspective. Richards and Rodgers (2001) explain that under the formal approach, "the goal of foreign language study is to learn a language in order to read its literature or in order to benefit from the mental discipline and intellectual development that result from foreign language study" (p. 5). So language form (vocabulary, imagery, figurative language, rhythm, metrics, grammatical and syntactic structure, and punctuation) becomes just a vehicle to access literature. Consequently, this method intends to develop mainly writing and reading skills as they are considered essential linguistic skills to analyze and interpret literary texts.

The Direct Method is another method that encourages the use of literary texts in the language class. It advocates direct target language use. Oral communicative skills and inductive grammar, without resorting to translation from the first language, are encouraged. Pronunciation and listening become central abilities, and literature is considered a good means to develop them. This approach changes the focus of study because language, rather than literature, is the object of study. However, literary resources are considered particularly important because they present different language forms inductively. They work as language samples for students to access different registers without paying specific attention to the study of grammar or any other formalistic structural component of language.

In the 1950s, the audio-lingual method was developed as a military teaching-learning strategy applied to learning languages. Its teaching techniques focus on constant oral repetition of dialogues and pattern practices to make students memorize sounds and structures of the foreign language of study. Under this approach, literature is only relevant as a means to provide input for repetition and verbal listening drills. Therefore, literary literacy is not significant. 
But the advent of the '80s and '90s marked a point of departure for most language teaching-learning strategies considered student-centered. In this context, the communicative language teaching methods gained popularity, and literature acquired a new dimension. These approaches propose the use of literature as a stimulus for discussion and genuine communication. For Richards and Rodgers (2001), communicative methods assume that individuals learn a language when using it communicatively in authentic and meaningful speaking contexts. Because the communicative language teaching methods are based on meaningful communication, it is thought that using literature in the classroom could stir up feelings and different perspectives in readers (students and teachers) as they can be encouraged to express emotions and opinions on what they read.

But teaching literature -particularly if it is written in a non-native language as is the case with English for many Costa Ricans- requires more abilities than just English language skills. Having good listening, speaking, reading, and writing skills in English does not imply the ability to teach literature in English. In this regard, Showalter (2002) states that when a foreign language teacher does not have clear knowledge of literature, teachers may experience "the anxiety of teaching" (p. 20) in the process of teaching English in addition to literature. Shell (2005) also argues that "teachers and lecturers may sometimes find it even more difficult to justify the inclusion of literature in their lesson plans" (p. 86) if they have not been accurately trained to identify and handle the potential of a literary text in the language classroom. Therefore, one cannot take the abilities and benefits of teaching literature for granted because they are not automatic results of language mastery. To enjoy these benefits, one must first have developed the required literary knowledge and abilities to face the challenge of teaching literature through the communicative means of a foreign language.

In the Costa Rican context of English teaching, it is necessary to put into perspective the fact that many English foreign language teachers may experience the "anxiety of teaching" because their basic academic training is in language rather than literature teaching. Teacher opposition to this method, a lack of interest and/or training to approach English through literature, among many other factors, can be easily translated into both "anxiety of teaching and learning" (Showalter, 2002).

As a result, negative emotions can emerge, producing unhealthy teaching and learning environments. From a neurolinguistic perspective, Renck and Hirsh (2010) explain that:

Reading and fear connect in the same way that classical conditioning operates. An initially neutral stimulus (e.g., reading aloud) is repeatedly paired with a noxious unconditioned stimulus (e.g., teacher judgment, peer ridicule) and as a result of this pairing, the learner forms an association between reading and negative emotions. (p. 27)

These authors also state that reading requires the development of a particular kind of sensitivity in relation to the object of study. The text combined with the teaching-practice-stimulus can reduce or intensify feelings of fear, frustration and anxiety, a lack of motivation and even phobias towards reading in both students and teachers. All these emotions foster unhealthy educational processes in the teaching of literature and English; in fact, they distort and hinder teaching and learning.

Reading anxiety is another aspect to consider. According to Brantmeier (2005), there are two approaches to explain the presence of reading anxiety in foreign language teaching and learning processes: the cognitive and the pedagogical perspectives. In the first case, memory, vocabulary processing, comprehension processes and attention span are cognitive aspects that influence reading and the analysis of any literary text. On the other hand, the way teachers and students deal with cognitive aspects may or may not foster interest, motivation, or positive attitudes during the reading and interpretation processes. Saito (1999) also warns that the unfamiliar script/writing system and unfamiliar cultural material are strong latent sources of anxiety in any language teaching and learning process that requires reading and interpretation.

On the other hand, it is also necessary to consider the academic perspective of the content that the MEP proposes in order to develop the English literature syllabus. Mastering key terminology and procedures for textual interpretation demands a complex process before one can actually foster communication of 
ideas. Under the MEP's proposal, students and teachers need to know and clearly understand the meaning and application of many terms and processes associated with the field of literary criticism, which transcends EFL instruction. Such a situation can create a methodological conflict between the principles of the communicative and the content-based approaches. In light of the linguistic, emotional, theoretical, and pedagogical issues mentioned, the benefits of using literature in the EFL classroom cannot be assumed as given.

Consequently, the positive outcomes of incorporating English literature classes in EFL teaching and learning processes involve many academic, socio-cultural and affective circumstances that affect reading and the process of interpretation. In a wider sense, all the aforementioned negative aspects can be minimized when teachers are academically and professionally prepared to face such challenges.

\section{Results}

\subsection{Teachers' Academic Background}

In terms of academic degrees, ${ }^{2}$ Experimental Bilingual High Schools are mainly hiring teachers with licenciaturas and the MT-6 qualification. ${ }^{3}$ This policy is very beneficial because it tends to guarantee a high level of academic training in teachers responsible for literature, as shown in figure 1:

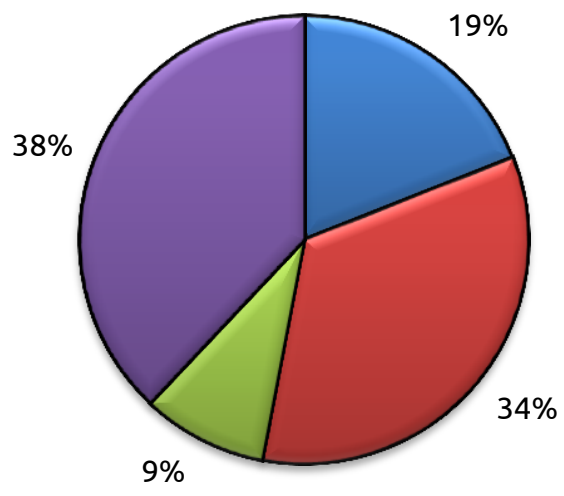

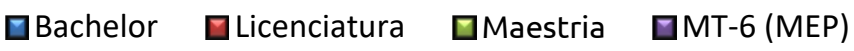

Figure 1. Percentage of participants with an academic degree and MT-6 certificate

Source: Data obtained from the questionnaire given to teachers of English literature at the Experimental Bilingual High Schools of the Western Educational Region of Costa Rica, November 2012.

\footnotetext{
${ }^{2}$ At the university level, the Costa Rican educational system offers four different degrees: bachelor's (this is different to the high school diploma), "licenciatura", master's and Phd. The bachelor's degree usually takes four years of professional and academic preparation. The "licenciatura" generally requires two more years (one course year plus one research project year). Master's programs usually entail two to three years of study and require the elaboration of a research thesis. Finally, the Phd usually takes four years. In the private educational system, the number of years of study needed in any of the aforementioned degrees is considerably reduced. Consequently, the bachelor's and "licenciatura" degrees are considered as undergraduate programs even though the latter requires a research project, which in the U.S. educational context is only required at the postgraduate level.

${ }^{3}$ This category is assigned to teachers who have a licenciatura plus some other educational courses they have to take at a certified university to achieve higher academic and financial status in the MEP's hiring system.
} 
Only $9 \%$ of teachers had a master's degree and $34 \%$ of the participants had a Licenciatura. On the other hand, $38 \%$ of the participants had an MT6 certification, ${ }^{4}$ the highest academic category for the MEP. This means that only $19 \%$ of teachers had just a B.A. degree. In this respect, results show that most teachers have high academic backgrounds in the field of EFL teaching. These results are consistent with the TOEIC qualification they have received as they are identified in the B1, B2 and C1 bands.

In regard to teachers who hold a B.A., $57 \%$ of the participants obtained their degree at the Universidad de Costa Rica, Carlos Monge Campus; 2\% at the Universidad de Costa Rica, Rodrigo Facio Campus; 35\% of teachers graduated from Universidad Latina; $4 \%$ graduated from Universidad Nacional; and 2\% graduated from Universidad Hispanoamericana. Teachers who hold a licenciatura graduated from Universidad Latina (9 teachers), Universidad de Costa Rica (1 teacher from Carlos Monge Campus and 1 from Rodrigo Facio Campus) and Universidad Hispanoamericana (1 teacher). Thus, $75 \%$ of licenciados graduated from Universidad Latina. In the case of teachers with a master's degree, all of them also graduated from Universidad Latina. This means that most teachers holding a B.A. graduated from public universities, particularly from the Universidad de Costa Rica (Carlos Monge Campus). Universidad Latina is the higher education institution with the second highest number of graduates. But participants' undergraduate and postgraduate degrees such as the "licenciatura" and master's degrees are mainly obtained at private institutions with Universidad Latina leading teachers' academic choices. Thus, most teachers who obtain a B.A. have attended public universities, but they migrate to private institutions to earn their licenciatura, master's degree and/or MT6 category.

Another significant result is related to academic majors. It is important to highlight that $3 \%$ of the teachers majored in linguistics while $97 \%$ majored in teaching English as their primary B.A. major. Based on the information obtained through the survey and by analyzing the universities' academic programs, there are no professors majoring in teaching literature as there are no universities that offer this program in Costa Rica, even though some universities offer degrees in literature, as is the case of the master's degree program in English literature from the Universidad de Costa Rica, their focus is not on teaching literature. In addition, teachers have not had the opportunity to study abroad in countries where teaching literature is a common major in arts and science faculties. This represents an issue for EFL teachers, for Costa Rican universities and for the whole educational process proposed for EBHS because EFL teachers are taking on a professional challenge they have not been academically trained for. In this respect, the group of instructors, as a whole, reports that they have not taken any other literature courses besides the ones shown in table I.

\footnotetext{
${ }^{4}$ This means that $72 \%$ of teachers are "licenciados" because the MT6 certification requires that teachers hold a "Licenciatura". The MT6 certification is a category only the MEP assigns to those teachers who obtain the "Licenciatura" degree in their major plus some additional educational courses that certify them as elementary school teachers.
} 
Table I. Literature courses offered in the B.A. and licenciatura programs of the universities teachers graduated

\begin{tabular}{|c|c|c|}
\hline Institution & Bachelor & Licenciatura \\
\hline \multirow{4}{*}{$\begin{array}{l}\text { Universidad de Costa Rica, } \\
\text { Sede de Occidente }\end{array}$} & U.S. literature (mandatory) & Elective courses: \\
\hline & British literature (mandatory) & Literature from English-speaking \\
\hline & Comparative literature (mandatory) & regions and its relationship to \\
\hline & & $\begin{array}{l}\text { contextual issues, Cinema and } \\
\text { literature }\end{array}$ \\
\hline \multirow{12}{*}{$\begin{array}{l}\text { Universidad de Costa Rica, } \\
\text { Sede Rodrigo Facio }\end{array}$} & Classic literature for modern languages (mandatory) & \\
\hline & Introduction to drama (mandatory) & \\
\hline & Introduction to poetry (mandatory) & \\
\hline & Overview of U.S. literature (mandatory) & \\
\hline & Overview of British literature (mandatory) & \\
\hline & Literary criticism (mandatory) & \\
\hline & Introduction to English literature (elective) & \\
\hline & Children's literature (elective) & \\
\hline & Mystery and suspense literature (elective) & \\
\hline & Women and literature (elective) & \\
\hline & Cinema and literature (elective) & \\
\hline & Contemporary literature (elective) & \\
\hline \multirow[t]{5}{*}{ Universidad Nacional } & U.S. literature and culture & \\
\hline & Multi-ethnic literature & \\
\hline & Victorian literature & \\
\hline & Poetry, drama and tragedy & \\
\hline & $\begin{array}{l}\text { (Students only had to take two courses of these four } \\
\text { because the other two were elective choices) }\end{array}$ & \\
\hline \multirow[t]{5}{*}{ Universidad Latina } & Introduction to literature (mandatory) & \\
\hline & Introduction to narrative (mandatory) & \\
\hline & Introduction to drama (mandatory) & \\
\hline & Introduction to poetry (mandatory) & \\
\hline & Literary criticism (mandatory) & \\
\hline Universidad & Literature I (mandatory) & Literature II (mandatory) \\
\hline Hispanoamericana & & Literature III (mandatory) \\
\hline
\end{tabular}

Source: Authors' elaboration based on the analysis made of the academic curricular programs of the universities teachers graduated from, July 2013.

It can be said that all teachers have taken at least one course related to English literature at the undergraduate level and one more for licenciatura, which is negligible if one considers the professional task they have been given by the MEP. The Universidad de Costa Rica, Campus Rodrigo Facio and Universidad Latina are the institutions with the strongest literary orientation in their curricula. The former offers six mandatory courses, but students also have the possibility to choose from six courses to complement their background knowledge of literature. However, it is important to state that complementary courses are elective choices. At the Universidad de Costa Rica (UCR), Campus Rodrigo Facio, students can choose from six elective courses according to their needs and preferences (students can decide how many elective courses they would like to take). In this respect, it is important to point out that only $2 \%$ of teachers have had such strong academic training in the literary field (those who graduated from Universidad de Costa Rica, Campus Rodrigo Facio). This university provides students with six mandatory courses in different literary genres as well as various elective courses that students can enroll in to improve their professional literary knowledge. All courses are offered at the bachelor level. At first glance, this data could seem positive but one has to remember that $98 \%$ of teachers obtained their B.A. degree at other universities. Therefore, having only $2 \%$ of teachers with a strong literary academic training becomes statistically insignificant in terms of the impact this curriculum has on the Western Educational Region of Costa Rica where teachers are working.

In the case of UCR, Campus Carlos Monge Alfaro, the bachelor program is made up of three mandatory courses related to U.S., British and Comparative literatures. This means that most teachers (59\%) have taken these courses, as presented in table III. 
For those who have a master's degree ( $9 \%$ of teachers), only one program includes a course on literature, and this is in universal literature (in the master's degree program offered by the Universidad Latina). The other major recorded at master's degree level is in linguistics (one teacher), and includes no literature courses. Therefore, not even postgraduate programs fulfill teachers' academic needs in the field of English literature teaching.

When teachers were asked about the importance of having a strong academic background in English literature, $11.4 \%$ of teachers stated that more courses in the subject are not necessary, but $88.6 \%$ of them signaled a need for courses that could help future teachers to teach literature. All teachers agreed that the academic training they received at university level did not give them the expertise they need to work with the MEP's English literature syllabus. This result is very significant because it suggests a new subject should be included in the current EFL academic programs of most Costa Rican universities, both private and public ones.

On the other hand, descriptions of all the courses stated in Table I reveal a content-based approach that privileges cultural and linguistic knowledge rather than the understanding of literary and didactic principles to teach English through literature. As complementary education, English literature courses are not designed to help future teachers to use literature as a resource for teaching. However, such contentbased courses are still perceived as useful by teachers as they all affirmed the importance of the literature course they took at university.

Courses with didactic orientations are also very relevant for participating teachers, as illustrated by table II.

Table II. Courses that teachers think that Costa Rican TESOL and EFL majors should offer to help future teachers implement the MEP's English literature syllabus

\begin{tabular}{lcc}
\hline Content-subject & Teachers' response \\
\hline & Frequency & $\%$ \\
\hline Teaching literature & 31 & 88.6 \\
U.S. literature & 29 & 82.9 \\
Poetry & 27 & 77.1 \\
Drama & 27 & 77.1 \\
Reading comprehension strategies & 26 & 74.3 \\
British literature & 25 & 71.4 \\
Narrative & 24 & 68.6 \\
Short stories & 24 & 68.6 \\
Comparative literature & 20 & 57.1 \\
Anglophone Costa Rican literature & 17 & 48.6 \\
Critical theory & 15 & 42.9 \\
Afro-Caribbean literature & 14 & 40.0 \\
Children's literature & 12 & 34.3 \\
Gothic literature & 6 & 17.1 \\
Others & 4 & 11.4 \\
\hline
\end{tabular}

Source: Data obtained from a questionnaire given to teachers of English literature in the Experimental Bilingual High Schools of the Western Educational Region of Costa Rica, November 2012.

Firstly, the most important course for teachers relates to teaching, as $88.6 \%$ of teachers believe that EFL programs should have courses with a pedagogical and didactic focus that could provide theoretical support in addition to strategies for teaching literature. Secondly, teachers indicated that programs should offer a course in literature produced by U.S. writers because it could provide them with cultural, historical, and literary background knowledge of this particular country. Similarly, $77.1 \%$ of teachers consider that courses in poetry and drama are necessary. These two choices are particularly interesting because they are very specific genres. When teachers were asked about these selections, they stated that the MEP's English literature syllabus places a strong emphasis on the study of poetry and drama. Reading comprehension is a skill teachers have to develop, which explains why $74.3 \%$ think that reading comprehension courses are very important. 
Conversely, less significant courses include comparative, gothic, children's, and English-language Costa Rican literature and Afro-Caribbean literatures. Only $57.1 \%$ of participants think that the comparative literature course (that most teachers took at the B.A. university level) is relevant because it does not have a significant professional impact on their daily work. More specific courses such as gothic and children's literature are the least important choices. To teachers, there is no real practical use of these genres as they are not part of the MEP's target content. In some other cases, teachers excluded the cited options because they did not have a clear idea of the possible content of those courses. In particular, this was the case with anglophone and Afro-Caribbean courses. When asked, most teachers stated that they had never heard of English-speaking Afro Costa Rican writers while Afro-Caribbean English and its literature are perceived as less prestigious than U.S. and British production.

Teachers' academic and professional needs, their preconceptions and lack of understanding of some literary genres are mainly caused by the scarce literary orientation of their university education. In regard to this issue, figure 1 shows that $6 \%$ of teachers took more than five English literature courses at their corresponding universities. As shown in figure 2, the rest of the sample has not had strong literary instruction.

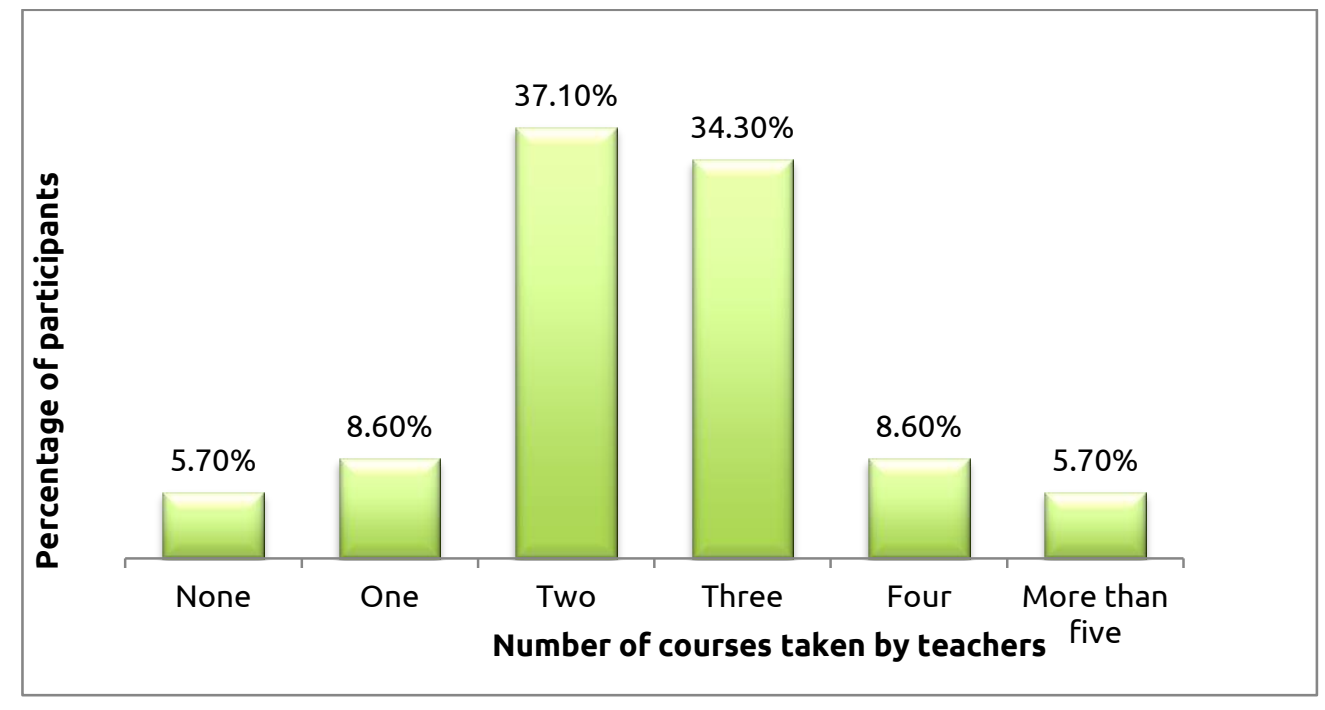

Figure 2. Number of English literature courses participants took at university level ${ }^{1}$

Source: Data obtained from questionnaire given to teachers of English literature in the Experimental Bilingual High Schools of the Western Educational Region of Costa Rica, November 2012.

${ }^{1} \mathrm{~N}=32$

Figure 2 confirms the results of the analysis of university programs. Literature is not a priority in undergraduate and postgraduate academic curricula. According to the English advisor of the Western Educational Region, "teachers from this region have expressed concerns regarding the implementation process of this proposal [the MEP's English literature program] because the courses teachers took at university did not include how to teach literature; they do not even know how to choose appropriate literary materials. They do not know how to assess students' performance" (Artavia, personal communication, June 10, 2013). The courses teachers stated they took at the university are the following: 
Table III. Type of literature courses participants took at university level

\begin{tabular}{lcc}
\hline Courses Taken by Participants & Frequency & $\%$ \\
\hline U.S. literature & 25 & 71.4 \\
British literature & 24 & 68.6 \\
Poetry & 18 & 51.4 \\
Drama & 17 & 48.6 \\
Short stories & 14 & 40 \\
Reading comprehension strategies & 11 & 37.4 \\
Narrative & 13 & 37.1 \\
Comparative literature & 13 & 37.1 \\
Teaching literature & 5 & 14.3 \\
Critical theory & 3 & 8.6 \\
Gothic literature & 2 & 5.7 \\
Children's literature & 2 & 5.7 \\
Afro-Caribbean literature & 2 & 5.7 \\
\hline
\end{tabular}

Source: Data obtained from a questionnaire given to teachers of English literature in the Experimental Bilingual High Schools of the Western Educational Region of Costa Rica, November 2012.

Most participants reported they took U.S. and British literature courses, which is consistent with the information provided in table III and figure 6. Drama and poetry are the two other courses most participants took. It is important to recall that these are mandatory courses for all teachers who obtained a B.A. From Universidad Latina and UCR, Campus Rodrigo Facio. They are also elective courses at Universidad Nacional. On the other hand, Afro-Caribbean, Gothic, and children's literature were barely mentioned. In terms of cultural identity, the absence of anglophone (English) Costa Rican literature also reveals the lack of interest in this area, even though it could enhance the teaching experience with highly contextualized literary materials.

Teachers were also asked about the quality of the courses they took. In this respect, most teachers pointed out that the suitability of the courses' objectives must be improved in regard to their professional needs. From their perspective, many courses are poorly contextualized in the MEp's working scenarios. 


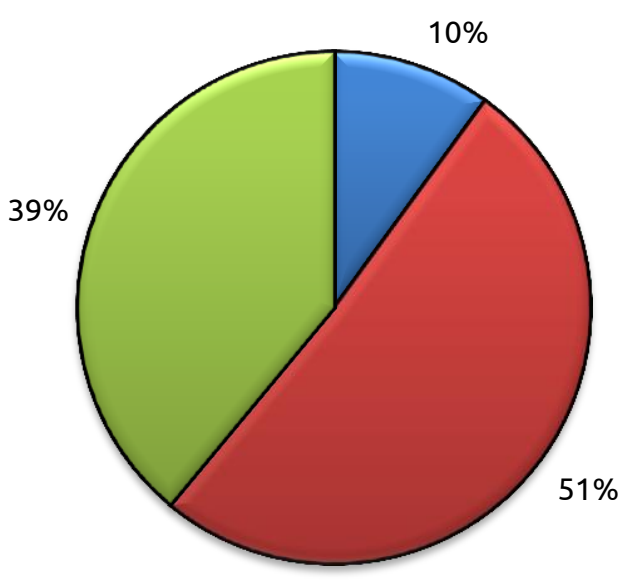

\section{口Highly Contextualized QRelatively Contextualized aPoorly Contextualized}

Figure 3. Teachers' opinions about the suitability of the objectives of courses taken at university in regard to the needs of their profession ${ }^{1}$

Source: Data obtained from a questionnaire given to teachers of English literature in the Experimental Bilingual High Schools of the Western Educational Region of Costa Rica, November 2012.

${ }^{1} \mathrm{~N}=32$

Figure 3 shows that $90 \%$ of participants consider that the courses they took at university lack contextualization. For these teachers, there was no clear theoretical connection with their profession due to the absence of a well-defined teaching orientation that could help them put into practice the content they studied. Some teachers stated that "the aims of courses were to read stories, plays, and poems in order to analyze some literary elements, but never to focus on how to teach literature." Other participants expressed that "the university courses were very ambitious in terms of the amount of content, and superficial when referring to explanations and analyses. Time was always an issue." For example, one participant pointed out: "I can barely remember the content or the stories. I remember by heart the names and lives of authors, but they were not significant." Consequently, as shown in figure 4, most courses taken at university level were not considered very useful: 


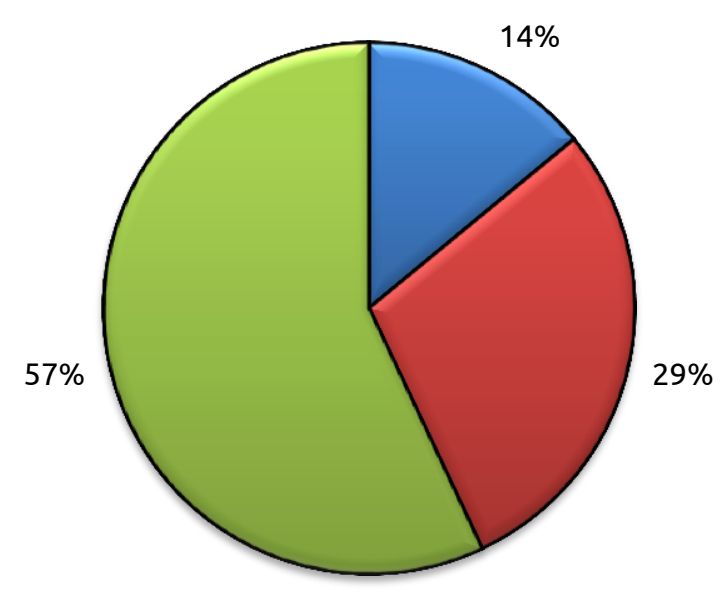

口Not useful aVery useful aRelatively useful

Figure 4. Percentages of teachers' opinions about the usefulness of the content of courses taken at university level in regard to the needs of the profession ${ }^{1}$

Source: Data obtained from a questionnaire given to teachers of English literature in the Experimental Bilingual High Schools of the Western Educational Region of Costa Rica, November 2012.

${ }^{1} \mathrm{~N}=32$

Only $14 \%$ of teachers thought that the courses they had taken at university were not useful to carry out their job in EBHS. The majority, $57 \%$, were partially satisfied with the literary orientation they received, as courses had been relatively useful for teaching English literature. Finally, 29\% of participants believed that literature courses had given them the basic background knowledge they needed to implement the MEP's English literature syllabus.

\subsection{MEP's Opportunities for Training}

Another important aspect of teachers' knowledge of literature is the professional training they have undertaken after finishing higher education. To keep up with recent developments, professionals need to constantly participate in workshops, courses and conferences. As a result, effective training can be achieved through efforts carried out not only by individuals but also through institutional support and commitment. Figure 5 illustrates the incidence of further training teachers have received in order to teach literature in EBHS. 


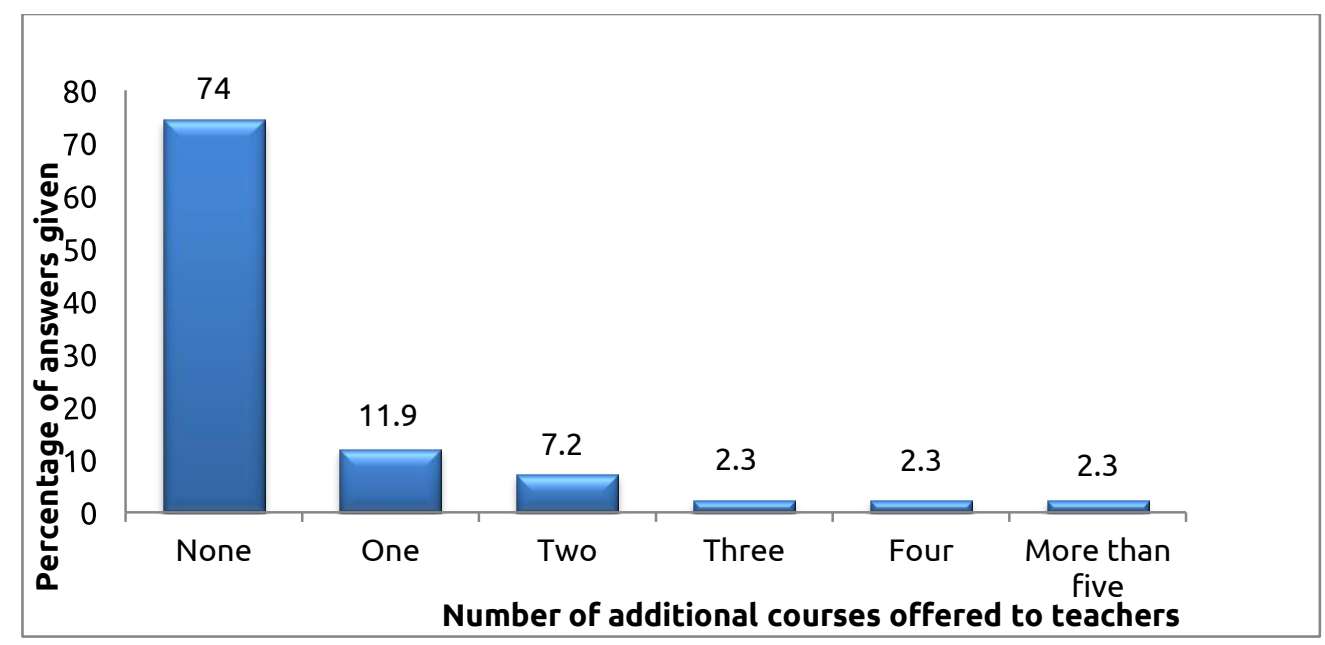

Figure 5. Number of additional courses on teaching literature that the MEP or other institutions have offered to participants

Source: Data obtained from a questionnaire given to teachers of English literature in the Experimental Bilingual High Schools of the Western Educational Region of Costa Rica, November 2012.

Training is another issue that teachers and the MEP authorities have to deal with. Clearly, most teachers (74\%) have never received professional training from the MEP or other institutions to teach literature. According to Artavia, taking all the literature teachers out of the classroom is difficult, and therefore training opportunities are very limited. Along with the fact that the MEP is placing EFL teachers in a difficult professional dilemma, it is not offering significant academic training to implement its educational proposal in EBHS.

\section{Conclusions}

In regard to teachers' academic training, the analyzed programs present various deficiencies that affect teachers' capacity to face the English literature teaching process in EBHS. It is important to point out that most teachers have very high levels of education as $72 \%$ of them hold at least a "licenciatura" degree (38\% are just licenciados plus $32 \%$ who are also licenciados but hold the MT- 6 certification). The fact that only $19 \%$ of the participants hold a B.A. shows a genuine governmental action aimed at hiring more highly qualified teachers. This is certainly a positive aspect. However, all bachelor-level credentials are in the field of English teaching and not in teaching literature, which is an issue.

There is an institutionalized fallacy in the belief that any EFL teacher can teach English literature just because he/she masters the language. Programs do not have a strong literary orientation. Except for the cases of Universidad de Costa Rica, Campus Rodrigo Facio and Universidad Latina where the curriculum offers five mandatory literature courses, B.A. programs have a maximum of three courses related to the study of English-language literature and/or literary genres as content-based subjects. This situation is one of the main weaknesses identified in this study. Despite the fact that UCR, Campus Rodrigo Facio and Universidad Latina have a particular literary basis in their B.A. curriculum, the professional and academic impact such training may have in the English literature teaching process is not relevant if one takes into consideration that only $37 \%$ of teachers graduated from those institutions.

In the case of licenciatura and master's programs, the inclusion of literature courses is even more deficient than what the B.A. programs offer. Teachers obtained their licenciatura at the UCR, Campus Carlos Monge and the Universidad Hispanoamericana. Neither of these two institutional programs trains students to teach literature. On the one hand, the licenciatura program at UCR, Campus Carlos Monge only has two elective courses (Literature of English-speaking countries, and Cinema and Literature), and this course is not a regular option for students. Therefore, most teachers did not have the chance to take the 
elective course in literature. On the other hand, the Universidad Hispanoamericana program has two mandatory courses on literature but, as is also the case at the UCR, Campus Carlos Monge, their contents and objectives are not pedagogically geared towards using literature as a means of developing students' communicative competence. Instead, most courses focus on cultural and literary knowledge of Englishspeaking countries from a historic and cognitive complementary perspective. Regarding the master's programs, one is in linguistics, which excludes the study of literature, and the other one is in EFL teaching, in which case teachers only have the opportunity to take one course, on universal literature.

As a result, it can be said that all the participants have taken at least two literature courses at university, which is important but not really significant in terms of acquisition of literary and pedagogical abilities. These subjects have provided them with a cultural and literary perspective to develop their teaching experience. They are offered at bachelor's level, which provides a basic introduction to the field of literature.

Nevertheless, an average of $79 \%$ of teachers believed that Costa Rican TESOL and EFL majors should offer mandatory courses on U.S. literature, poetry, drama, British literature and reading comprehension, but teachers also warned that this academic background knowledge is insufficient to fulfill the MEP's expectations regarding the implementation of the English literature syllabus. Even though $79 \%$ of teachers believed that the English literature courses they took at university were important, $88.6 \%$ think that more teaching courses need to be offered if they are to meet their professional and academic needs.

As complementary education, the literature courses of the stated programs have not been designed to use literature as a pedagogical resource. This academic situation is a constant complaint among participants. That is why most teachers (88.6\%) think that courses on teaching literature are an urgent need. In this same respect, another drawback is that some of the literature courses included in the different university programs are offered as electives instead of mandatory subjects, which does not guarantee core academic background knowledge among teachers who graduate from the same institution.

In addition, the academic training teachers received is questionable in light of the MEP's demands. It lacks contextualization and applicability in the educational EFL process undertaken in the EBHS. As $90 \%$ of the participants indicated, the contents and objectives of the courses they took at university are not really contextualized in the Costa Rican EFL classrooms, particularly in EBHS English literature classes. Firstly, the MEP's proposal is very recent. Secondly, the literary orientation of university programs is culturally, and not pedagogically, justified. This means that in university programs, literature courses are taken as a cultural rather than a didactic component.

At the national level, there is also an almost total absence of training opportunities in the field of teaching literature for EFL teachers. Neither the MEP nor private/public institutions are offering courses, workshops, conferences or any other academic activity that could help reinforce and improve teachers' literary expertise. According to teachers, the MEP has not given them any academic training to expand their knowledge of literature; $74 \%$ of the participants indicated that they had not had the chance to participate in courses (besides the ones taken at the university) related to the study and use of literature for EfL teaching purposes. Only 3 teachers, out of 37, have participated in more than three courses offered by non-ministerial institutions. In other words, the MEP has delegated the responsibility of professional training to teachers who do not find real opportunities to acquire knowledge in the field. There is a generalized feeling regarding the absence of courses, conferences and workshops that can connect the study of literature to the EFL educational contexts of EBHS, and in this sense, there has not been an appropriate induction process to help teachers develop the MEP's proposal. Teachers are fully aware of their limitations, so they are requesting training and better educational processes in the field of literature. This is definitely a positive situation.

The few existing training programs have not taken into consideration teachers' opinions about their needs. Additionally, there is no current permanent training to teach literature. This academic and administrative situation presents a major professional dilemma for EFL teachers who are dealing with English literature. The MEP (2010) justifies the teaching of literature from an artistic and aesthetic 
perspective that orchestrates the potential benefits of combining language and literature to learn English. Such a perspective is an important strength in philosophical terms. But the MEP has just assumed that EFL teachers can also teach English literature, as if both subjects and processes were the same, which is a fallacy. This assumption constitutes one of the main drawbacks in the process of implementing the English literature syllabus - not because teachers are not capable of implementing it, but because they have not been trained to accomplish the task. Therefore, teaching anxiety is increasing to the extent that many teachers view the literature classes as punishment.

Finally, it is of utmost importance to study the educational and professional context that EFL teachers are facing in implementing the English literature syllabus. It is necessary to systematize teachers' opinions and recommendations to improve the current MEP's pilot syllabus to teach English literature and language. The researchers hope that the results of this study might be relevant for universities, MEP authorities, and Costa Rica Multilingüe as they provide valuable information that can be used to offer teachers new training courses in literature.

\section{References}

Buendía, E. L. (1998). La Investigación por Encuesta. [Surveyresearch]. Métodos de investigación en psicopedagogía (pp. 119-155). Barcelona: McGrawHill.

Brantmeier, C. (2005). Anxiety about L2 reading or L2 reading task? A study with advanced language learners. The Reading Matrix, 5, 67-83.

Creswell, W. J.(2003). Research design qualitative, quantitative, and mixed methods approaches. California: Sage.

Ministerio de Educación Pública, Ministerio de Comercio Exterior, Ministerio de Economía, Industria y Comercio, Instituto Nacional de Aprendizaje, Coalición Costarricense de Iniciativas de Desarrollo, Proyecto Estrategia Siglo XXI. (2008). Plan Nacional de Inglés Costa Rica Multilingüe Setiembre 2008. Retrieved from

http://www.competitividad.go.cr/ bibliotecaimages/documentos/Plan\%20Nacional\%20de\%20Ingles.pdf

Ministerio de Educación Pública. (2010). Programa de literatura en lengua inglesa de liceos experimentales bilingües, plan piloto [Experimental Bilingual High Schools English Language Arts Program, Pilot Plan]. San José, Costa Rica: Ministerio de Educación Pública-Imprenta Nacional.

Ministerio de Educación Pública, Ministerio de Comercio Exterior, Ministerio de Economía, Industria y Comercio; Instituto Nacional de Aprendizaje, Coalición Costarricense de Iniciativas de Desarrollo, Proyecto Estrategia Siglo XXI. (2011). Informe 3er año de labores Programa Costa Rica Multilingüe, 2011. [3rd year Work Report Costa Rica Multilingual Program, 2011]. San José, Costa Rica. Retrieved from http://www.siwastudio.com/PDF/CRML_INFORME.pdF

Renck, J. M. \& Hirsh, R. A. (2010). Understanding reading anxiety: New insights from neuroscience. Early Childhood Education Journal, 1(37), 431-435

Richards, J. \& Rodgers, T. (2001). Approaches and methods in language teaching (2 ${ }^{\text {nd }}$ ed.). New York: Cambridge University Press.

Saito, Y., Horwitz, E., \& Garza, J. (1999). Foreign Language Reading Anxiety. The Modern Language Journal, 83, 202-218. Retrieved from http://dx.doi.org/10.1111/0026-7902.00016

Shell, J. (2005). Why teaching literature. Encuentro, 1 (15), 86-93.

Showalter, E. (2002). Teaching literature. Oxford: Blackwell. 